\title{
DISTURBANCE, POLLINATOR PREDICTABILITY, AND POLLINATION SUCCESS AMONG COSTA RICAN CLOUD FOREST PLANTS ${ }^{1}$
}

\author{
Peter Feinsinger \\ Department of Zoology, University of Florida, Gainesville, Florida 32611 USA
}

JAMES H. BEACH

Bureau of Biological Research, Rutgers University, P.O. Box 1059, Piscataway, New Jersey 08854 USA

YAN B. LINHART

Department of EPO Biology, Box 334, University of Colorado, Boulder, Colorado 80309 USA

AND

William H. Busby and K. Greg MURRAY ${ }^{2}$

Department of Zoology, University of Florida, Gainesville, Florida 32611 USA

\begin{abstract}
Cloud forest at Monteverde, Costa Rica experiences frequent natural disturbance. To determine whether species interactions vary spatially due to physical heterogeneity produced by disturbance, we examined relationships between 22 plant species and 11 nectar-feeding bird species in 14 study plots distributed among three patch types: large landslide-like gaps (hand-cleared areas along a trail), small gaps (formed by recent treefalls), and understory of closed-canopy forest.

Species we describe here flowered in two or three patch types. The aspects of pollination we examined varied little with patch type. Mean frequency of pollinator visits varied with patch type in a few plant species but not in most, and there was no significant trend across species. Pollen loads carried by 314 mist-netted hummingbirds did not vary significantly with patch type, either in total number of grains or number of species represented. $\mathrm{Cu}$ mulative pollen loads that hummingbirds deposited on stigmas of two species of Acanthaceae (Razisea spicata and Hansteinia blepharorachis) did not vary consistently with patch type, except that Hansteinia flowers in treefall gaps received fewer heterospecific pollen grains than flowers in the other two patch types. Frequency of fruit set varied significantly with patch type in three of the four species examined, but the direction of variation in one of these was opposite to the direction of the other two. The absolute frequency with which flowers were pierced by nectar-robbing hummingbirds did not vary significantly with patch type, although the frequency of piercing relative to legitimate pollinator visits did increase in the large gaps. We attribute the latter result to aggregation of the hummingbird Eupherusa eximia, a chronic nectar robber, at dense clumps of longflowered plant species that occurred in large gaps. Only one feature we examined suggested that patch type might directly affect the nature of species interactions: in two different analyses, the level of variation in frequency of hummingbird visits to flowers declined from large gaps to small gaps to forest.

Results suggest that, unless the disturbance initiating a patch is unusually severe or widespread, interactions between the plants and hummingbirds examined are insensitive to patch type. Such species, existing in naturally dynamic forests throughout their recent evolutionary histories, presumably have become accommodated to frequent small-scale disturbance. Results also suggest that those habitat-related contrasts in plant reproductive traits and plant-pollinator interactions documented in other studies, which compare habitats initiated by anthropogenic disturbances with undisturbed patches, may be artifacts to some extent. Anthropogenically generated disturbance mosaics may promote the spread of species whose reproductive traits evolved under very different circumstances from mosaics generated by natural disturbances.
\end{abstract}

Key words: cloud forest; Costa Rica; disturbance; fruit set; hummingbirds; patch dynamics; pollen; pollination; succession; treefall gaps.

\footnotetext{
1 Manuscript received 30 January 1986; revised 5 November 1986; accepted 4 December 1986.

${ }^{2}$ Present address: Department of Biology, Hope College, Holland, Michigan 49423 USA.
} 


\section{INTRODUCTION}

In many natural landscapes, frequent small-scale disturbances and less frequent larger scale disturbances create mosaics of habitat patches recently disturbed and patches that by chance have not been disturbed for some time (Whittaker and Levin 1977, Connell 1978, White 1979, Sousa 1984, Pickett and White 1985). For example, many tropical forests are mosaics of intact, closed-canopy regions ("mature-phase" patches sensu Whitmore 1978), quite small "gap-phase" patches created by falling trees and other disturbances of moderate intensity, larger gap-phase patches created by phenomena such as landslides (Garwood et al. 1979), and "building-phase" patches from earlier disturbances (Brokaw 1985). The nature of species interactions is thought to vary spatially with the physical heterogeneity that such natural disturbance produces (Levin 1976, Pickett 1976, Whittaker and Levin 1977, Thompson 1982, Sousa 1984, 1985, Schowalter 1985).

Spatial variation in the efficacy of animal pollination (e.g., see Parrish and Bazzaz 1979, Collins et al. 1985), for example, is one of many possible causes for the consistent differences in phenotypic traits between plant populations occupying intensively disturbed habitats and those occupying less disturbed sites (e.g., see Baker 1959, 1965, 1974, Gadgil and Solbrig 1972, Cruden 1976, 1977, Jain 1976, Werner and Platt 1976, Abrahamson 1978, Newell and Tramer 1978, Oka 1983). Among plants occupying recently or intensely disturbed sites, obligate outbreeding, or breeding systems requiring animal pollination at all, occur less frequently than among plants of undisturbed sites (e.g., see Stebbins 1957, 1958, Baker 1959, 1965, Grant 1975, Cruden 1976, 1977, Jain 1976). Among obligately animalpollinated species, flower size and reliance on specialized, large-bodied pollinators increase with increasing successional maturity (Parrish and Bazzaz 1979, Opler et al. 1980). Thus it is often inferred that plants dependent on pollination by animals, especially large, specialized flower-visitors, experience an increase in pollination success with a decrease in the frequency, area, or intensity of disturbance.

Whether or not pollinator efficacy varies among the patches of a natural disturbance mosaic is unknown. Most previous studies on floral traits and breeding systems with respect to disturbance compare plants occupying habitats created by large, anthropogenic disturbances (e.g., agricultural old fields) with plants present in natural, "undisturbed" communities. The few studies that explicitly explore variation in pollinator efficacy with habitat also involve anthropogenic disturbances whose scale and intensity may greatly exceed that of naturally occurring disturbances (e.g., Parrish and Bazzaz 1979). Presumably, floral traits of many species evolved under natural disturbance regimes characterizing presettlement landscapes. We report here on a single set of hummingbird-pollinated plant species exposed to three patch types (small gap-phase patches, large gap-phase patches, intact or mature-phase forest) in a tropical cloud forest at Monteverde, Costa Rica, and evaluate the extent to which predictability of animal pollinators and frequency of successful pollination vary in systematic ways among these patch types.

\section{METHODS}

\section{Choice of system}

Neotropical plants adapted for hummingbird pollination provide an appropriate group in which to examine disturbance-related variation. Even though they include few trees (Stiles 1978, 1981), plants adapted for hummingbird pollination are common in all other growth forms (Stiles 1978, 1981), with representatives in numerous families. These plants are important constituents of understory and epiphytic canopy vegetation at many mid- and high-elevation neotropical sites (Cruden 1972, Stiles 1978, 1981, 1985, Snow and Snow 1980). At other sites interactions between tropical hummingbirds and plants are known to vary with habitat (Stiles 1978, 1981, Feinsinger 1983), for example between adjacent undisturbed and human-disturbed habitats (Linhart 1973, Stiles 1975, Feinsinger 1978), or between island and mainland sites (Feinsinger et al. 1979, 1982, Linhart and Feinsinger 1980).

\section{Study sites}

The Monteverde Cloud Forest Reserve, near Monteverde, Provincia de Puntarenas, Costa Rica, is a 5100ha tract composed chiefly of pristine Lower Montane Rain Forest (Holdridge 1967). This forest is continuous with much larger expanses of protected montane forest on the crest and Atlantic slope of the Cordillera de Tilarán. Lawton and Dryer (1980) describe the vegetation in detail. Except for a single livestock trail and several footpaths, the Cloud Forest Reserve has been little influenced by humans. Some pasture weeds, such as Rubus rosaefolia, Sida spp., and Impatiens sultanii, occur along the livestock trail, but otherwise the Reserve lacks exotic species (for example, the honeybee Apis mellifera is absent).

The Monteverde cloud forest is strongly influenced by northeast trade winds, which carry clouds and mist over the continental divide. Although measurable precipitation decreases during the November-to-May windy season, the habitat in which we worked, Leeward and Windward Cloud Forest (Lawton and Dryer 1980), remains wet year-round. Trade winds and steep slopes also lead to high rates of disturbance. Gaps created by falling limbs and trees are frequent. Murray (1986) has estimated that such events disrupt $\approx 1.5 \%$ of the canopy cover per year, such that turnover time is $\approx 67 \mathrm{yr}$. These figures are well within the range exhibited by other wet neotropical forests (Brokaw 1985) and by temperate deciduous forests as well (Runkle 1985). Canopy gaps caused by treefalls at Monteverde 
range from $<10$ to $>500 \mathrm{~m}^{2}$, with a median area of $\approx 35 \mathrm{~m}^{2}$. Landslides occur on steep slopes. Although much less frequent than treefalls, landslides disrupt larger areas. Those occurring on the Pacific-facing slopes in Leeward Cloud Forest (Lawton and Dryer 1980) typically devastate an area of $\approx 16 \times 100 \mathrm{~m}$. Landslides sweep both vegetation and soil cover from a central swath (5-10 $\mathrm{m}$ wide), and most vegetation from a belt on either side.

In June 1981 we set up study plots in three "patch types": mature-phase cloud forest with a closed canopy (hereafter termed "forest"), small gap-phase patches ("treefalls"), and large gap-phase patches. Four forest plots, located wherever we could find sufficiently large expanses free from recent disturbances and at least 20 $\mathrm{m}$ from existing gaps, ranged from 1600 to $1925 \mathrm{~m}^{2}$ and totalled $7280 \mathrm{~m}^{2}$. Six treefall plots, totalling 2300 $\mathrm{m}^{2}$, encompassed treefall gaps ranging from 132 to 544 $\mathrm{m}^{2}$. We selected gaps created by two or more trees falling 1-3 yr previously, and included representatives of the two vegetation types occurring in treefall gaps at that elevation (gaps dominated by large herbs, in particular Heliconia, and gaps dominated by shrubs of several families). For safety reasons, we did not use recent landslide scars for large gaps. Instead, in January 1980 we had cleared four large patches along the livestock trail, interspersed among the other study sites. The four "cutovers," which ranged from 1155 to 2442 $\mathrm{m}^{2}$ and totalled $7380 \mathrm{~m}^{2}$ exclusive of the bare trail down the center of each, differed from true landslide scars in slope and soil conditions. During 1982-1983 we compared flowering plants and foraging hummingbirds on these cutover plots with monthly censuses on a nearby landslide scar of similar age and physiognomy. These data revealed that the vegetation on the cutovers was quite similar to that in the regenerating belts of vegetation at either side of the landslide's central swath. There were no floristic anomalies so great as to disqualify the cutovers for use as experimental large gaps (Linhart et al. 1987). They resembled the nearby landslide scars in size, shape, and important physical features. Furthermore, composition of nectarfeeding bird assemblages was nearly identical between the cutovers and the landslide-caused gaps, as it was similar between cutovers and all other habitats we investigated (Feinsinger et al., in press).

\section{Censuses and observations}

On the first of each month from July 1981 through June 1982 , on each of the 14 study plots we counted all flowers of plant species used by nectar-feeding birds, to a height of $10 \mathrm{~m}$ in forest plots. During the subsequent month we determined the frequency with which hummingbirds and other birds visited the flowers of each plant species in each patch type. Species flowering in more than one patch type during a given month were observed separately in each. In each patch type, each of the three most abundantly flowering plant species received at least three replicate observations (in different sites of that patch type when possible) that month. Observations began at dawn (0510 to 0540 depending on time of year) and lasted $6 \mathrm{~h}$. During an observation period (which sometimes included flowers of two or more plant species), we noted every foraging bout, recording the number of flowers visited during the bout. We distinguished "legitimate" flower visits, in which the bird probed the corolla opening and contacted reproductive parts, from "piercing" visits, in which the bird entered the corolla from the side (either creating a hole, using an existing hole, or, in some flowers, probing between unfused petals) and failed to contact the reproductive parts. We noted arthropod visitors to flowers. For the 12 mo we recorded 12813 flower-visits by birds during 4218 plant-hours of observation.

For each 6-h observation period, we calculated frequency of legitimate visits per flower per $6 \mathrm{~h}$ and frequency of piercing (illegitimate) visits. We also calculated diversity of (legitimate) visitors as:

$$
D=\frac{1}{\sum_{i=1}^{S} p_{i}{ }^{2}},
$$

where $p_{i}$ is the proportion of flower-visits made by the $i^{\text {th }}$ bird species $(i=1-S)$.

For this study, most investigations were confined to the herb, shrub, and treelet layers, including low-growing epiphytes. Bird-pollinated Ericaceae and some Bromeliaceae in the forest canopy form a somewhat distinct pollination assemblage (cf. Feinsinger and Colwell 1978, Stiles 1985). Visit frequencies to flowers of canopy Ericaceae were monitored closely by W. H. Busby (personal observation).

\section{Pollen loads carried by birds}

We mist-netted birds for $2 \mathrm{~d}$ per patch type per month, rotating the study sites involved. Using clear plastic tape, we carefully removed pollen from the bill, head plumage, and throat plumage of each of 314 hummingbirds netted during the 12-mo period. One piece of tape was laid down dorsally from the bill tip to the nape of the neck, pressed down and gently rubbed, peeled off from the tip back, and mounted on a microscope slide. A second piece of tape sampled the underside of the bill and the entire throat. All pollen grains on each slide were later counted and matched with vouchers as far as possible, using compound microscopes equipped with a $40 \times$ Hoffman objective. For the analysis reported here, data from the upper and lower samples from each bird were combined. Counts of grains and species are conservative for two reasons. (1) Although we attempted to collect pollen loads as soon as birds had entered the mist nets, undoubtedly some pollen was lost as birds struggled. (2) Pollen grains of some closely related species are indistinguishable. 
TABLE 1. Plant species visited by nectar-feeding birds on study plots in the Monteverde Cloud Forest Reserve and used in this analysis. Each observation lasted the first six daylight hours.

$\begin{array}{ccc} & n \\ \text { Species } & \text { Growth form } & \begin{array}{c}\text { obser- } \\ \text { vations }\end{array}\end{array}$

A. Flowers adapted for pol-

lination by long-billed

hummingbirds ("long

flowers")

Acanthaceae

Justicia aurea Schidr.

Poikilacanthus macranthus Lindau

Razisea spicata Oersted

Bromeliaceae

Pitcairnia brittoniana Niez

Gesncriaceae

Alloplectus tetragonus (Oerst.) Hanst.

Capanaea grandiflora

(Kunth) Decne ex Pl.t

Columnea magnifica Cersted

Columnea microcalyx Fanstein

Drymonia conchocalyx Morton

Drymonia rubra Morton

Heliconiaceae

Heliconia tortuosa Grigg

Lobeliaceae

Centropogon solanifolius Benth.*

Malvaceae

Malvaviscus palmanus Shrub or Pittier \& DonnellSmith

Rubiaceae

Ravia triflora Oerst.

Symplocaceae

Symplocos sp. (povedeae?**

Zingiberaceae

Costus barbatus Suess.*

B. Flowers adapted for pol-

lination by short-billed

hummingbirds ("short

flowers")

Acanthaceae

Dicliptera trifurca Oersted

Hansteinia blepharorachis (Leonard) Durkee

Gesneriaceae

Besleria triflora (Oerst.) Shrub 56 Hanst.

Besleria formosa Morton

Lobeliaceae

Burmeistera cyclostigmata Donn. Sm.

Burmeistera tenuifolia Donn. Sm.*

Epiphyte 12

Climber 25

Climber $\quad 53$

Herb 44

Herb

Treelet

Epiphyte

Epiphyte
TABle 1. Continued.

\begin{tabular}{clc}
\hline \hline Species & Growth form & $\begin{array}{c}n \\
\text { obser- } \\
\text { vations }\end{array}$ \\
\hline Rubiaceae \\
Cephaelis elata Sw. & $\begin{array}{c}\text { Shrub or } \\
\text { Treelet } \\
\text { Shrub }\end{array}$ & 49 \\
$\begin{array}{c}\text { Gonzalagunia rosea } \\
\text { Standl. §,* } \\
\text { Palicourea lasiorrachis } \\
\text { Benth. ex Oerst.* }\end{array}$ & Shrub & 26 \\
$\begin{array}{c}\text { Palicourea macrocalyx } \\
\text { Standl.\| }\end{array}$ & Shrub & 15 \\
\hline
\end{tabular}

* Species used in visit-variability analysis reported in Fig. 1 and Table $5 \mathrm{~A}$ but not used in other analyses reported here (except Justica aurea, also used in fruit-set study reported in Table 9).

$\dagger$ Pollen also carried by short-billed hummingbirds; apparently adapted for bat rather than bird pollination, but no nocturnal observations were made.

\$ Possibly adapted for nocturnal visitors, although probably hummingbird pollinated.

$\S$ Very little pollen carried by hummingbirds; apparently adapted for pollination by arthropods (bees, also wasps and lepidopterans).

|| Pollen carried by hummingbirds but also by hymenopterans and butterflies.

Pollen loads deposited on stigmas

Following procedures described in detail by Feinsinger et al. (1986), we examined pollen loads on stigmas of two species of Acanthaceae that flowered abundantly in all three patch types, Hansteinia blepharorachis and Razisea spicata, each belonging to a different pollination guild (see Results: Plant Species). On 26 January 1983, we made an unsystematic collection of Razisea stigmas from plants growing in each of the three patch types; we did the same for Hansteinia on 9 February 1983. Each stigma was examined with an epifluorescence microscope, and the numbers of conspecific and heterospecific pollen grains were recorded. Both species examined are self-compatible (Feinsinger et al. 1986). These data do not overlap with those published by Feinsinger et al. (1986).

\section{Frequency of fruit set}

From October 1981 through January 1982 we examined frequency of fruit set in four species. Large numbers of unmanipulated flowers were marked and followed through to fruit maturation. Alloplectus tetragonus (Gesneriaceae), Razisea spicata, and Hansteinia blepharorachis were examined in all three patch types. Another species of Acanthaceae, Justicia aurea, rarely flowered in forest; we compared fruit set between plants growing in treefalls and cutovers.

\section{RESULTS}

\section{Plant species}

At Monteverde, data on flower visitors demonstrated that plants adapted for hummingbird pollination made up two pollination guilds (sensu Root 1967, see 
TABLE 2. Birds observed to visit flowers on study plots in the Monteverde Cloud Forest Reserve.* In each category, species are listed in descending frequency of flower visits.

A. Long-billed hummingbirds

Phaethornis guy (Green Hermit)

Campylopterus hemileucurus (Violet Sabre-wing)

Heliodoxa jacula (Green-crowned Brilliant) $\dagger$

Doryfera ludovicae (Green-fronted Lancebill)

Eugenes fulgens (Magnificent Hummingbird)

B. Short-billed hummingbirds

Lampornis calolaema (Purple-throated Mountaingem)

Eupherusa eximia (Stripe-tailed Hummingbird)

Panterpe insignis (Fiery-throated Hummingbird)

Elvira cupreiceps (Coppery-headed Emerald)

Selasphorus scintilla (Scintillant Hummingbird)

C. Passerine

Diglossa plumbea (Slaty Flower-piercer)

* Note that some species seen to visit flowers were not mistnetted (see Table 3), whereas one species mist-netted was not observed to visit flowers on the plots and thus is not listed here.

† Technically, a hummingbird of moderate length bill (see Feinsinger and Colwell 1978; Feinsinger et al. 1985), but among understory plants it visited exclusively (and legitimately) those with long flowers.

Feinsinger et al. 1986). Those with tubular corollas $\leq 25 \mathrm{~mm}$ long received legitimate visits almost exclusively from hummingbirds with correspondingly short bills ( $<25 \mathrm{~mm}$ total culmen length). Those with corollas $\geq 30 \mathrm{~mm}$ long received legitimate visits primarily from hummingbirds with correspondingly long, often curved, bills ( $\geq 28 \mathrm{~mm}$ total culmen). Our study sites contained a total of 20 long-flowered plant species and 13 short-flowered plant species (Linhart et al. 1987) exclusive of canopy or subcanopy Ericaceae. Here, we discuss 15 long-flowered species and 7 short-flowered species (Table 1); others were observed too infrequently for statistical analyses.

Table 1 also lists some species that may not be primarily adapted for hummingbird pollination. Capanea grandiflora, frequently visited by long-billed hummingbirds (and occasionally by short-billed hummingbirds), has large, open, nectar-rich, dull-covered flowers that, except for absence of odor, suggest the possibility of bat pollination. We did not make nocturnal observations. Nevertheless, hummingbirds often carried large numbers of Capanea pollen grains. Although we did not see any flower visitors other than hummingbirds, Burmeistera cyclostigmata may likewise attract nocturnal visitors; open flowers are odorless but unopened buds exude a strong, skunky odor (Y. B. Linhart, personal observation). The white to pale blue flowers of Palicourea macrocalyx attract many short-billed hummingbirds, which carry numerous pollen grains, but they also attract hymenopterans and a few lepidopterans. Finally, although Gonzalagunia rosea provided a major food source for hummingbirds in cutover study plots, only rarely did hummingbirds carry Gonzalagunia pollen, which undoubtedly was carried much more frequently by the numerous hymenopteran and lepidopteran visitors. With these exceptions, however, the plants in Table 1 are dependent on hummingbirds for nonautogamous pollinations ( $\mathrm{J}$. $\mathrm{H}$. Beach et al., personal observation). Although all species but the Rubiaceae appear to be self-compatible, only Pitcairnia brittoniana, Heliconia tortuosa, and occasionally the Lobeliaceae are capable of autogarny ( $\mathrm{J}$. $\mathrm{H}$. Beach et al., personal observation). Therefore, the frequency of hummingbird visits and the contents of the pollen loads that hummingbirds deposit may significantly affect sexual reproduction in these plants.

\section{Bird species}

Eleven bird species visited flowers we observed (Table 2). Phaethornis guy made $68.2 \%$ of the legitimate visits to long flowers (Feinsinger et al. 1986). Lampornis calolaema made $96.9 \%$ of the visits to short flowers. Eupherusa eximia was responsible for most remaining visits to short flowers, but far more often made piercing visits to long flowers. The passerine flower-piercer Diglossa plumbea rarely visited flowers in the herb-shrub layer, instead concentrating on flowers in the canopy. Although treefalls tended to have the highest species richness of flower-visiting birds, hummingbird species composition did not differ markedly among patch types (P. Feinsinger et al., personal observation).

\section{Pollen loads carried by birds}

We collected no pollen whatsoever from some hummingbird individuals (e.g., Eupherusa eximia), but other individuals carried as many as 16 distinguishable species of grains (Table 3). Species richness of pollen loads did not vary with patch type for any one bird species (Table 3A.1). Neither the frequency of birds carrying no pollen whatsoever nor the diversity of grains carried by the other individuals varied significantly with patch type (Table 3A.2). Finally, the number of pollen grains carried did not vary significantly with patch type (Table 3B), partly because the nearly significant trends in different bird species ran in opposite directions and cancelled one another out.

\section{Frequency of legitimate visits}

We restricted analyses of visit frequencies to plant species observed $\geq 3$ times per patch type: eight longflowered and three short-flowered species examined over all three patch types (Fig. 1A); one long-flowered species (Capanea) and two short-flowered species examined in cutovers and treefalls only (Fig. 1B); and three long-flowered and two short-flowered species examined in treefalls and forest only (Fig. 1C). As Fig. 1 shows, in most species mean visit frequency appeared to shift with patch type, but variation within patch types was also high. For each species observed in all three patch types, we performed a Kruskal-Wallis test (Siegel 1956) for effect of patch type, or a Mann-Whitney $U$ test for species observed in two patch types only. 
TABLE 3. Pollen loads collected from hummingbirds mist-netted in the three patch types. (A) Number of pollen species per bird (conservative estimates; see Methods: Pollen Loads Carried by Birds). (B) Number of pollen grains per bird (conservative estimates; see Methods: Pollen Loads Carried by Birds).

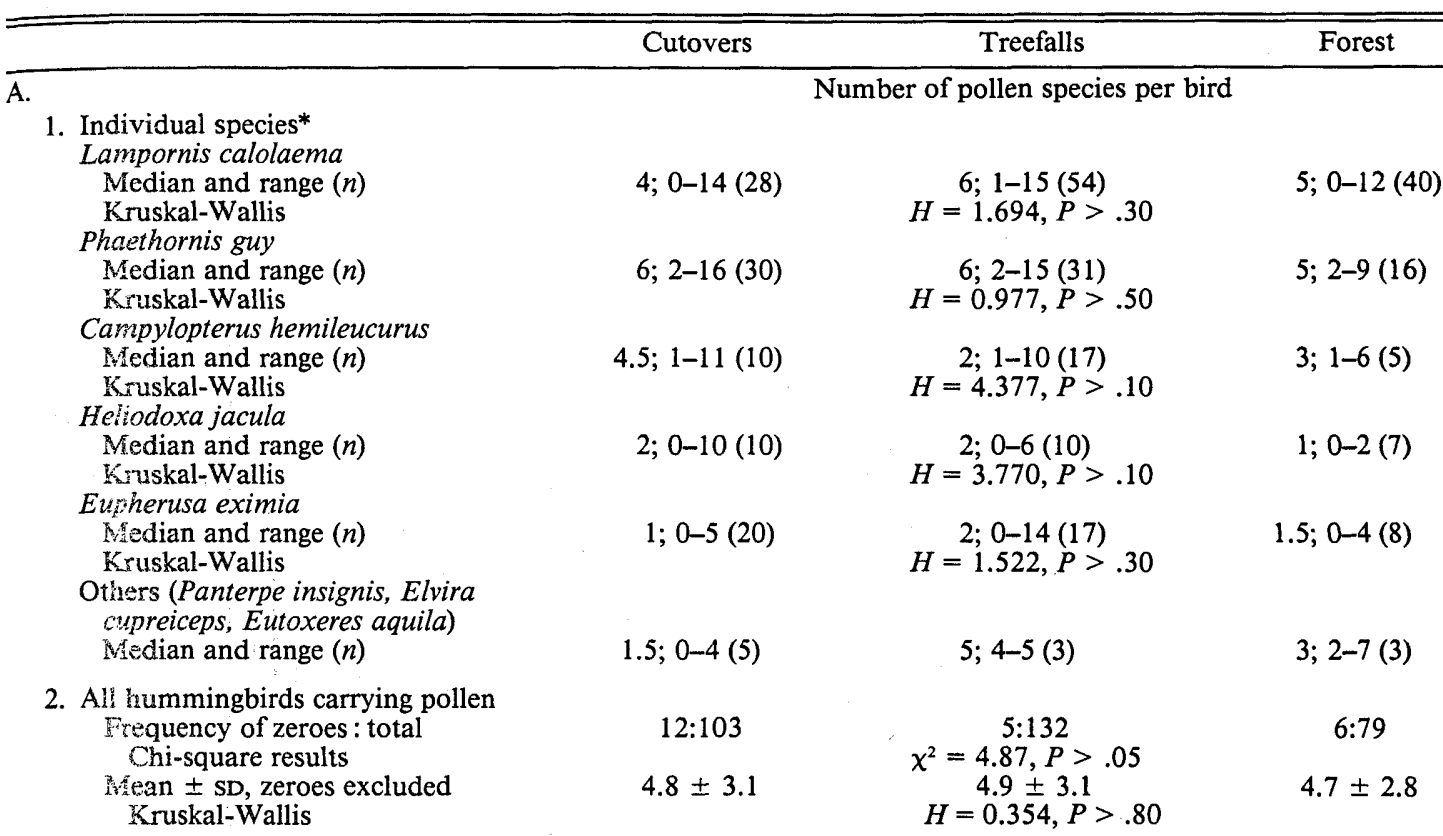

B.

1. Individual species

Lampornis calolaema

Mean \pm SD $(n)$

Median

$886 \pm 1753(28)$

Kruskal-Wallis

Phathornis guy

Mean $\pm \mathrm{SD}(n)$

Median

Kruskal-Wallis

Campylopterus hemileucurus

wean \pm SD $(n)$

Median

Kuruskal-Wallis

Heliodoxa jacula

Mean \pm SD $(n)$

Median

Kruskal-Wallis

Eipherusa eximia

Mean \pm SD $(n)$

Median

Kruskal-Wallis

Others

Mean $\pm \operatorname{SD}(n)$

Median

Kruskal-Wallis

2. All hummingbirds
Mean $\pm \operatorname{SD}(n)$
Median
Kruskal-Wallis$$
1172 \pm 2199(103)
$$$$
215
$$$$
367 \pm 782(10)
$$$$
103 \pm 209 \text { (20) }
$$$$
2.5
$$

Number of pollen grains per bird

$$
\begin{aligned}
& 1394 \pm 1793(54) \\
& 644 \\
& H=5.705, P>.05 \\
& 2226 \pm 2747(31) \\
& H=3.064, P>.20 \\
& 757 \pm 563 \text { (17) } \\
& H=2.355, P>.30 \\
& 175 \pm \underset{5}{356}(10) \\
& H=1.088, P>.70 \\
& 318 \pm 900 \text { (17) } \\
& H=2.008^{4}, P>.30 \\
& 3944 \pm 6533(3) \\
& 276 \\
& H=3.103, P>.20 \\
& \begin{array}{l}
1334 \pm 2110(132) \\
514 \\
H=3.622, P>.10
\end{array} \\
& 342 \pm \underset{39}{608(5)} \\
& 34 \pm \underset{3}{81(7)} \\
& 478 \pm 1003(8) \\
& 136 \\
& 160 \pm 249(3) \\
& 21 \\
& 1267 \pm 2528(79)
\end{aligned}
$$

${ }^{*}$ Birds carrying no pollen included.

To evaluate effect of patch type on visit frequencies across plant species, we performed two-way parametric ANOVAs after adding 1 to each datum, log-transforming, and checking for homoscedasticity. One two-way ANOVA was performed for long-flowered species alone, then another for all species regardless of corolla length.
Visit frequency did not vary significantly with patch type in any single species that we examined in all three patch types (Fig. 1A). Of species examined in only two patch types (Fig. 1B, C), Palicourea macrocalyx experienced a significant decline from treefalls to forest, where we never observed a bird visit during $18 \mathrm{~h}$ of 
A.
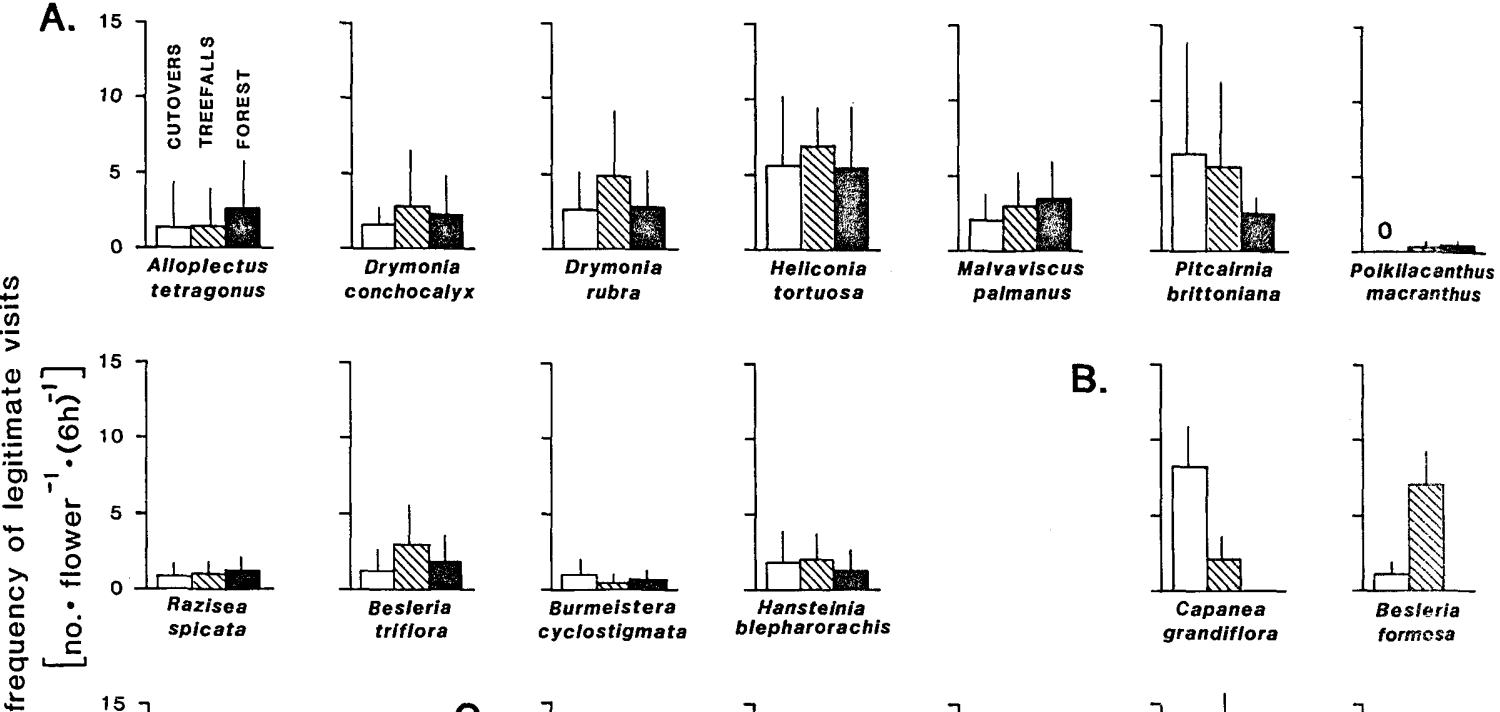

B.
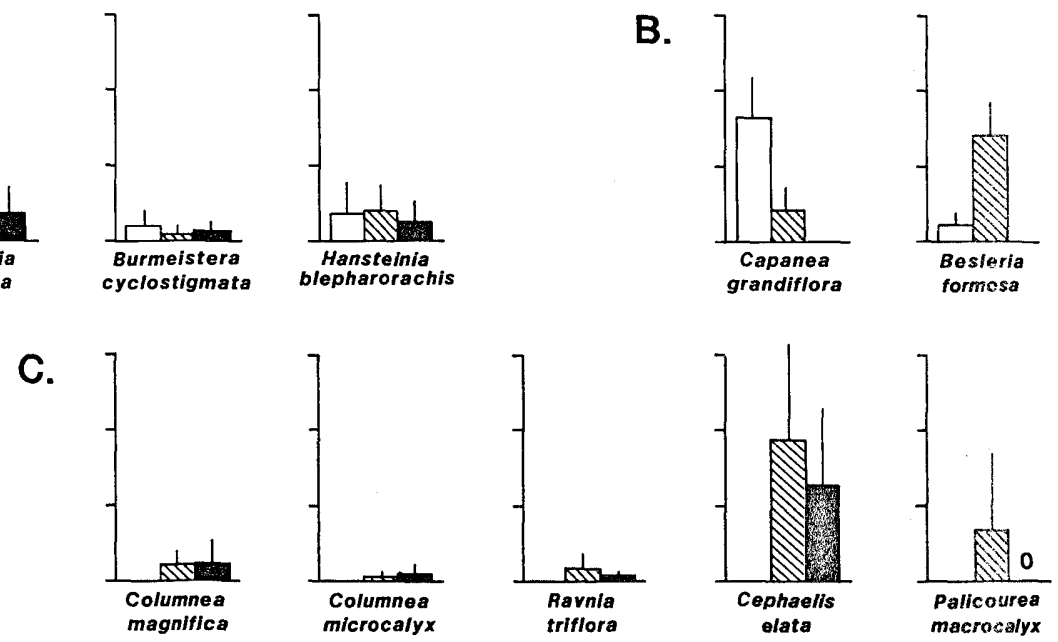

FIG. 1. Frequencies of legitimate (potentially pollinating) visits by hummingbirds to species observed at least three times (A) in each patch type; (B) in cutovers and treefalls only; (C) in treefalls and forest only. Height of bar indicates mean visit frequency over the $\geq 3$ observations, height of line above bar indicates standard deviation. In each subset (A, B, C), longflowered species are listed first.

observation. Two short-flowered species, Besleria formosa and Dicliptera, experienced significantly greater visit frequencies in treefalls than in cutovers, but $\mathrm{Ca}$ panea experienced the reverse. Considering all species observed in all three patch types or those in treefalls and forest only, there was no significant effect of patch type on visit frequency among all species or among long-flowered species only (Table 4.1, 4.2).Visit frequencies in the remaining species (Fig. 1C) increased from treefalls to forest (Table 4.3), but the trend in one species countered that in the other two (Fig. 1).

We calculated coefficient of variation (CV) in visit frequency among $\geq 3$ replicate observations made on each of the three most abundantly flowering bird-visited species in each patch type in a given month. These species included most but not all of those in Fig. 1, and included several listed in Table 1 but not shown in Fig. 1. The Kruskal-Wallis ANOVA treated each $\mathrm{CV}$ as a variate. Whether or not the analysis included Gonzalagunia, whose dependence on hummingbird visits is highly doubtful, median CV declined from cutovers through forest (Table 5A). Pairwise comparisons (cf. Hollander and Wolfe 1973: 125) showed that the considerable decrease from cutovers to treefalls was responsible. Secondly, for species observed $\geq 3$ times in each patch type (Fig. 1A) we calculated CV over all observations, regardless of month, within a given patch type. Again, we treated each $\mathrm{CV}$ as a variate and performed two-way Friedman ANOVAs (Siegel 1956). Again, variability declined from cutovers to forest (Table 5B). In pairwise comparisons (Hollander and Wolfe 1973: 151), only the cutover-forest differences were significant.

\section{Diversity of legitimate visitors}

Diversity of visitors arriving at a plant did not vary significantly with patch type (Table 6).

\section{Frequency of piercing visits}

All hummingbirds visiting short flowers, even $E$ upherusa eximia, did so legitimately, although on occasion bees ripped flowers open in all patch types. In contrast, some long-flowered species experienced frequent robbery by hummingbirds (Fig. 2). For example, during several observation periods Poikilacanthus received piercing visits only, all from Eupherusa eximia. We analyzed frequencies of piercings in the same ways as frequencies of legitimate visits, performing KruskalWallis analyses on data from individual species and performing parametric ANOVAs on coded and logtransformed data for cross-species comparisons. Ab- 
TABLE 4. Effects of patch type on mean frequency of hummingbird visits to flowers (height of bars in Fig. 1). Only records of legitimate (=potentially pollinating) visits are included.

\begin{tabular}{|c|c|c|c|}
\hline & $F^{*}$ & df & $P \dagger$ \\
\hline \multicolumn{4}{|l|}{$\begin{array}{l}\text { 1. Plant species observed }>3 \\
\text { times/patch type }\end{array}$} \\
\hline $\begin{array}{l}\text { a. Long-flowered plants } \\
\text { (8 species) }\end{array}$ & 1.27 & 2,250 & .28 \\
\hline b. All plants ( 11 species) & 1.67 & 2,360 & .19 \\
\hline \multicolumn{4}{|l|}{$\begin{array}{l}\text { 2. Plant species observed }>3 \\
\text { times in treefalls and forest } \\
\text { only }\end{array}$} \\
\hline $\begin{array}{l}\text { a. Long-flowered plants } \\
\text { ( } 3 \text { species) }\end{array}$ & 0.09 & 1,28 & .76 \\
\hline b. All plants ( 5 species) & 3.52 & 1,82 & .06 \\
\hline \multicolumn{4}{|l|}{$\begin{array}{l}\text { 3. Plant species observed }>3 \\
\text { times in cutovers and treefalls } \\
\text { only }\end{array}$} \\
\hline a. All plants (3 species) & 7.19 & 1,24 & $.01 \ddagger$ \\
\hline
\end{tabular}

* In the two-way ANOVAs reported here, only those $F$ values for effect of patch type are reported; $F$ values for effect of plant species, of course, were nearly always significant; those for species $\times$ patch type interaction were never significant except where indicated.

† Here and in subsequent tables, alpha level for $F$

$\ddagger$ Highly significant plant species $\times$ patch type interaction because trend in Capanaea opposite to that of Besleria formosa and Dicliptera (see Fig. 1).

solute frequencies of piercings did not vary significantly with patch type, either over all species (Table 7A) or in any one species. Frequency of piercings relative to legitimate visits, however, did shift significantly with patch type (Table 7B); over all species, plants in forest experienced relatively fewer hummingbird piercings than plants in the two types of gaps we examined. Of individual species, Drymonia rubra experienced a sig- nificant effect of patch type on relative piercing frequency, but other species did not.

\section{Pollen loads deposited on știgmas}

Loads of conspecific pollen received by stigmas of short-flowered Hansteinia blepharorachis and Razisea spicata varied little with patch type (Table 8 ). The number of heterospecific grains that Hansteinia stigmas received varied significantly, with stigmas in treefalls receiving the fewest, but there is no evidence that heterospecific pollen grains inhibit fertilization in Hansteinia (S. Kinsman, personal observation).

\section{Frequency of fruit set}

In three of four species examined, frequency of fruit set varied significantly with patch type. The direction of variation was not consistent (Table 9). In Justicia aurea, which flowered profusely in cutovers and was frequently pierced by Eupherusa eximia there (see also McDade and Kinsman 1980, Willmer and Corbet 1981), fruit set increased from cutovers to treefalls. In Alloplectus, frequency of fruit set also increased from cutovers through forest, even though there was no habitat-related variation in the frequency of legitimate visits (Fig. 1A) or of pierces (Fig. 2A). In contrast, fruit set in Razisea declined from cutovers to forest, despite the absence of habitat effects on legitimate visit frequencies (Fig. 1A), frequencies of piercing visits (Fig. $2 \mathrm{~A}$ ), or pollen loads on stigmas (Table 8 ). Finally, the slight decline in Hansteinia fruit set from cutovers to forest was not significant.

\section{Discussion}

Among the species we examined, little evidence exists for spatial patterning of species interactions in re-

TABLE 5. Effect of patch type on relative variation (coefficient of variation) in frequency of hummingbird visits to flowers.* Values given are mean coefficient of variation $(\mathrm{CV})$ over all plant species in the particular patch type.

\begin{tabular}{|c|c|c|c|}
\hline & Cutovers & Treefalls & Forest \\
\hline \multicolumn{4}{|l|}{ A. Analysis of replicated observations $\dagger$} \\
\hline \multicolumn{4}{|l|}{ 1. With Gonzalagunia } \\
\hline Mean cv $(n)$ & $0.98(34)$ & $0.65(35)$ & $0.78(36)$ \\
\hline Kruskal-Wallis & & $H=9.71, P<.01$ & \\
\hline \multicolumn{4}{|l|}{ 2. Without Gonzalagunia } \\
\hline Mean CV $(n)$ & $0.93(28)$ & $0.65(35)$ & $0.78(36)$ \\
\hline $\begin{array}{l}\text { Kruskal-Wallis } \\
\end{array}$ & & $H=7.04, P<.05$ & \\
\hline \multirow{2}{*}{\multicolumn{4}{|c|}{$\begin{array}{l}\text { B. Two-way analyses, species } \times \text { patch type } \neq \\
\text { 1. Long-flowered plants }(7 \text { species })\end{array}$}} \\
\hline \multirow{2}{*}{\multicolumn{2}{|c|}{$\begin{array}{l}\text { 1. Long-flowered plants (7 species) } \\
\text { Mean cy }\end{array}$}} & & \\
\hline & 1.17 & 1.04 & 0.87 \\
\hline Friedman & & $\chi^{2}=6.00, P<.05$ & \\
\hline \multicolumn{4}{|l|}{ 2. All plants (10 species) } \\
\hline Friedman & 1.17 & $\chi^{2}=7.80, P<.05$ & 0.91 \\
\hline
\end{tabular}

* Only records of legitimate (=potentially pollinating) visits are included. Where no visits were observed during any replicate observation (twice on cutovers, once each in treefalls and forest), CV is undefined, so data are not included.

$\dagger$ Kruskal-Wallis nonparametric ANOVA on coefficient of variation among the 3 or more replicate observations per each of the 2-4 (usually 3 ) most abundantly flowering species per patch type each month (see Table 1, and Results: Frequency of Legitimate Visits), not necessarily the set of species represented in Fig. 1. Gonzalagunia rosea, in two months a major flowering species in cutovers, was primarily pollinated by insects.

$\ddagger$ Friedman nonparametric ANOVAs on species of Fig. 1 and with $\geq 3$ observations total in each of the three patch types. Data on Poikilacanthus excluded because flowers received 0 visits in cutovers, so $\mathrm{cv}$ is undefined. 
TABLE 6. Effects of patch type on diversity of flower visitors (Eq. 1). Only records of legitimate (=potentially pollinating) visits, and only observations with $>1$ visit recorded, are included. Data presented are grand (unweighted) mean of species means, for illustration only.*

\begin{tabular}{lccc}
\hline \hline & \multicolumn{3}{c}{ Mean (among-species) visitor diversity } \\
\cline { 2 - 4 } & Cutovers & Treefalls & Forest \\
\hline A. Long-flowered plants (7 spp.) & 1.18 & $F=2.10_{2,193}, P=.13$ & 1.11 \\
B. All plants (10 spp.) & 1.15 & $F=1.07_{2,285}, P=.35$ & 1.10 \\
\hline
\end{tabular}

* Effects were analyzed with two-way ANOVAs on species of Fig. 1 (except Poikilacanthus) with $\geq 3$ observations in each of the 3 patch types. Overall effects on species with $\geq 3$ observations in each of 2 patch types were not analyzed because the criteria in the legend eliminated most.

sponse to natural disturbance. With few exceptions, neither the predictability of hummingbird pollinators nor measures of pollination success declined significantly with increasing extent and intensity of disturbance. Occasionally, one plant species or another experienced variation in pollination that was related to patch type, but these idiosyncratic effects did not represent a broad trend among species as a group. The nature of the pollen loads carried by hummingbirds did not vary significantly with patch type (Table 3 ), nor did the mean frequency with which hummingbirds arrived at flowers (Fig. 1, Table 4), the diversity of visitors (Table 6), and, except for numbers of heterospecific pollen grains in one case, the pollen loads received by stigmas (Table 8). Although the frequency of fruit set varied with patch type in three of four species examined (Table 9), the effect was neither consistent among species nor clearly caused by pollination differences.

Of the two features we examined that did vary with patch type, at least one resulted from increases in floral density with disturbance rather than from disturbance directly. Unusually high densities of flowering Justicia aurea, Malvaviscus palmanus, and Heliconia tortuosa, as well as other species, characterized the cutover plots and some naturally occurring large gaps (Linhart et al. 1987). Although $H$. tortuosa experienced little nectar robbery, aggregations of other long-flowered species attracted the flower-piercing hummingbird Eupherusa eximia. In fact, unusually high densities of Malvaviscus arboreus (Webb 1984), Heliconia spp. (Stiles 1975), and Justicia aurea or other long-flowered Acanthaceae (McDade and Kinsman 1980, Willmer and Corbet 1981) also characterize large gaps or anthropogenic, highly disturbed sites elsewhere in Costa Rica, and attract other flower-piercing, short-billed huminingbirds there. Likewise, other long-flowered plant species at Monteverde, such as both Drymonia species and Razisea spicata, were often most dense in treefall gaps, where they suffered the most from Eupherusa (Fig. 2).

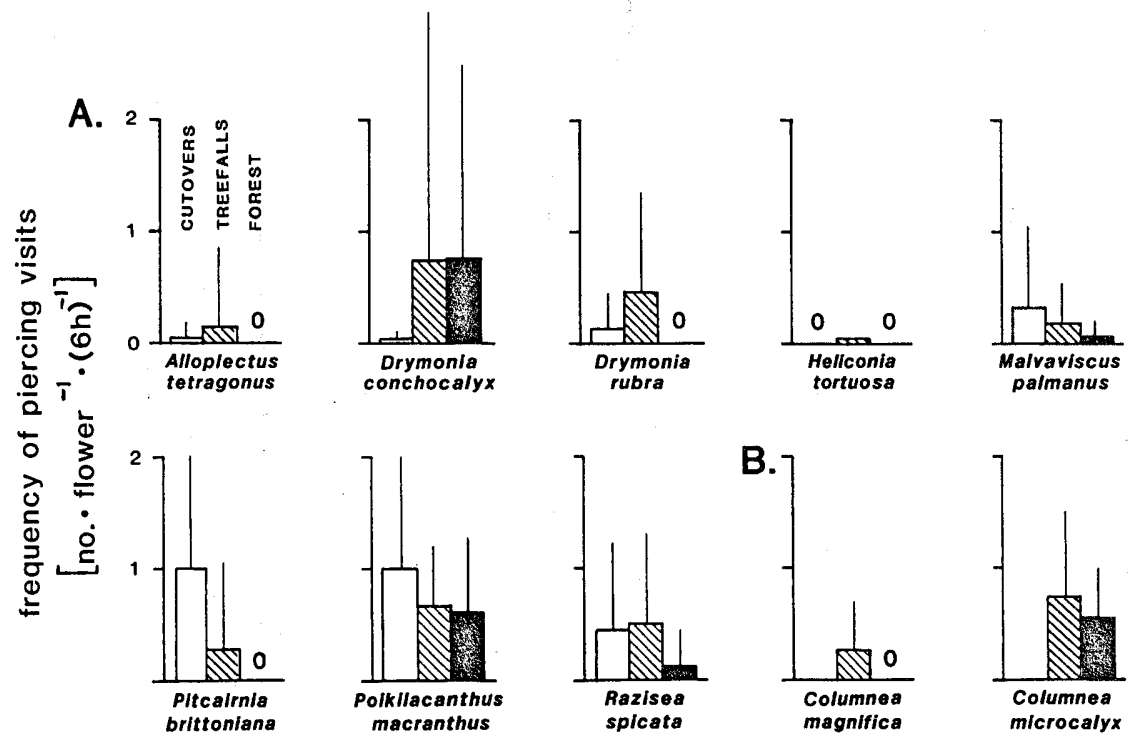

FIG. 2. Frequencies of piercing (nonpollinating) visits by hummingbirds to long-flowered species observed at least three times (A) in each patch type; (B) in treefalls and forest only. Height of bar indicates mean pierce frequency over the $\geq 3$ observations; height of line above bar indicates standard deviation. 
TABLE 7. Effects of patch type on frequency of nectar-robbing ("piercing") visits by birds to long flowers (Fig. 2).

\begin{tabular}{lll}
\hline & $F$ & $\mathrm{df}$ \\
\hline A. Absolute frequency of pierces per flower per 6-h observation & & \\
1. In species observed $\geq 3$ times/patch type (8 spp.) & 1.85 & 2,250 \\
2. In species observed $\geq 3$ times in treefalls and forest only (3 spp.) & 1.37 & 1,21 \\
B. Relative frequency of pierces (pierces/[pierces + legitimate visits]) & & .16 \\
1. In species observed $\geq 3$ times/patch type (8 spp.) & 3.49 & 2,250 \\
2. In species observed $\geq 3$ times in treefalls and forest only (3 spp.) & 0.65 & 1,21 \\
\hline
\end{tabular}

The net effect was an increase in the frequency of piercing, relative to the frequency of legitimate visits, from forest through cutovers (Table 7).

Plant-to-plant or day-to-day variation in frequency of legitimate visits also increased consistently from forest to cutovers (Table 5). This trend, which could affect variation in seed output or seed quality, might indicate a general tendency of large gaps or intense disturbance to disrupt plant-pollinator interactions. It is unlikely to be just a function of high densities of long flowers and Eupherusa eximia in large gaps, for adding short flowers (pierced neither by Eupherusa nor, with rare exceptions, by insects) to the analysis did not weaken the effect (Table 5).

In general, though, the cloud forest's disturbance mosaic had little influence on pollination by hummingbirds. Today's regime of frequent small-scale disturbance, and less frequent larger scale disturbance, has undoubtedly existed throughout these plant and bird populations' recent evolutionary history, and they have accommodated to it. Also, the scale of natural disturbance is small relative to the foraging range of hummingbirds. Elsewhere (Feinsinger et al., in press) we show that two bird species, Phaethornis guy and Lampornis calolaema, were responsible for $67 \%$ in cutovers, $74 \%$ in treefalls, and $88 \%$ in forest of the total nectar consumption by all birds. Individuals of these and other hummingbird species often foraged indiscriminately among patch types. Hummingbirds are not unique in this respect, however. Small animal pollinators such as bees, flies, or butterflies often fly shorter distances than robust pollinators such as hummingbirds, bats, or hawkmoths (Levin and Kerster 1974, Schmitt 1980, Waser 1982, Webb and Bawa 1983). Nevertheless, even small pollinators could easily traverse the distances among patches characterizing the disturbance mosaics of many temperate and tropical landscapes (Brokaw 1985, Runkle 1985). Thus, if scale alone were the determinant, any set of animal pollinators could be insensitive to the spatial pattern of a natural habitat mosaic.

Results suggest two conclusions. (1) Where reproductive biology differs among plants occupying different patch types of a natural disturbance mosaic (e.g., Werner and Platt 1976), spatial variation in pollinator effectiveness and pollination success may not be responsible. (2) The hypothesis that species interactions respond spatially to disturbance mosaics (e.g., Levin 1976, Pickett 1976, Whittaker and Levin 1977, Thompson 1982) must distinguish between natural disturbances and anthropogenic disturbances, which are not comparable. The size and intensity of many anthropogenic disturbances are well outside the range of natural disturbances that had been experienced by the site's native species. Consequently, many anthropogenic landscapes favor invasion by plants (and animals) with distant origins. Baker (1974), Kellman (1980), and Marks (1983), among others, suggested that many allochthonous weeds typical of "old fields" in the Western Hemisphere, temperate or tropical, evolved through the many millenia of human agriculture in the Old World. Marks (1983) also pointed out that many

TABLE 8. Effects of patch type on pollen loads received by stigmas of Hansteinia blepharorachis and Razisea spicata, both self-compatible species. See Methods: Pollen Loads Deposited on Stigmas and Feinsinger et al. (1986) for details on technique. Both species have 4 ovules/flower.

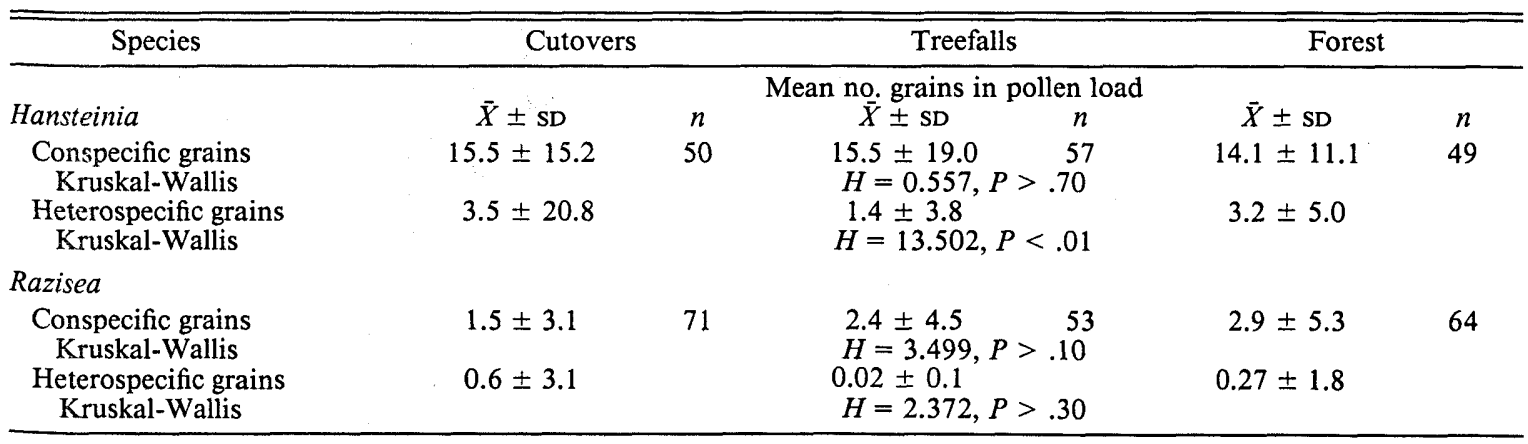


TABLE 9. Effect of patch type on frequency of fruit set from open pollinated flowers of four species.

\begin{tabular}{|c|c|c|c|}
\hline & $\begin{array}{l}\text { Cut- } \\
\text { overs }\end{array}$ & Treefalls & Forest \\
\hline & & Percent fruit set & \\
\hline Justicia aurea (680) & 4.7 & $\begin{array}{c}10.2 \\
\chi^{2}=7.41, \quad P<.01\end{array}$ & $*$ \\
\hline $\begin{array}{l}\text { Alloplectus tetra- } \\
\text { gonus (339) }\end{array}$ & 13.4 & $\begin{array}{c}19.0 \\
\chi^{2}=11.47, P<.01\end{array}$ & 32.1 \\
\hline $\begin{array}{l}\text { Razisea spicata } \\
\quad(660)\end{array}$ & 9.3 & $\begin{array}{c}1.7 \\
\chi^{2}=23.41, P<.001\end{array}$ & 1.2 \\
\hline $\begin{array}{l}\text { Hansteinia blepha- } \\
\text { rorachis }(811)\end{array}$ & 31.2 & $\chi^{2}=1.82, \quad P>.30$ & 26.5 \\
\hline
\end{tabular}

* Flowered only in cutovers and treefalls.

of the autochthonous old-field weeds, at least in the northeastern United States, evolved originally as small persistent populations occupying physically stressful sites unable to support forest, not as occupants of a natural disturbance mosaic. Plant traits relevant to pollination (Baker 1965, 1974, Grant 1975, Williams 1975, Jain 1976, Opler et al. 1980) and ecological interactions between plants and pollinators (e.g., Parrish and Bazzaz 1979) certainly vary among patches of a humaninfluenced landscape. These observations, however, bear no necessary relation to the patterning of species interactions over a natural landscape in which frequent small-scale disturbance is a part of the evolutionary heritage of extant plant and animal species.

\section{ACKNOWLEDGMENTS}

Carlos Guindon, Willow Z. Pounds, Rita Shuster, and James A. Wolfe collected many of the visit-frequency data; they and Sharon Kinsman, Carolina Murcia, Sarah Sargent, and Kathy A. Winnett-Murray helped to collect other data as well. We thank Wolf Guindon (Monteverde Cloud Forest Reserve), Joseph A. Tosi, Jr. (Tropical Science Center), and Roxana Diaz (Organization for Tropical Studies) for logistical help. Plant determinations were made by: W. Judd, K. Perkins, and D. Hall (University of Florida); W. Burger and P. Matekaitis (Field Museum); G. Davidse and R. E. Gereau (Missouri Botanical Garden); L. Skog (U. S. National Museum); and L. H. Durkee (Grinnell College). We thank H. G. Baker, J. Ewel, L. A. McDade, W. J. Platt, W. Z. Pounds, J. A. Pounds, A. Redmond, D. W. Schemske, and J. D. Thomson for criticizing earlier drafts. The study was supported by NSF grants DEB 80-11008 to Feinsinger and DEB 80-11023 to Linhart.

\section{Literature Cited}

Abrahamson, W. G. 1978. Patterns of resource allocation in wildflower populations of fields and woods. American Journal of Botany 66:71-79.

Baker, H. G. 1959. Reproductive methods as factors in speciation in higher plants. Cold Spring Harbor Symposium on Quantitative Biology 24:177-190.

- 1965. Characteristics and modes of origin of weeds. Pages 147-168 in H. G. Baker and G. L. Stebbins, editors. The genetics of colonizing species. Academic Press, New York, New York, USA.

-1974. The evolution of weeds. Annual Review of Ecology and Systematics 5:1-24.

Brokaw, N. V. L. 1985. Treefalls, regrowth, and community structure in tropical forests. Pages 53-69 in S. T. A. Pickett and P.S. White, editors. The ecology of natural disturbance and patch dynamics. Academic Press, New York, New York, USA.

Collins, B. S., K. P. Dunne, and S. T. A. Pickett. 1985. Responses of forest herbs to canopy gaps. Pages 218-234 in S. T. A. Pickett and P. S. White, editors. The ecology of natural disturbance and patch dynamics. Academic Press, New York, New York, USA.

Connell, J. H. 1978. Diversity in tropical rain forests and coral reefs. Science 199:1302-1310.

Cruden, R. W. 1972. Pollinators in high-elevation ecosystems: relative effectiveness of birds and bees. Science 176: 1439-1440.

-1976. Intraspecific variation in pollen-ovule ratios and nectar secretion - preliminary evidence of ecotypic adaptation. Annals of the Missouri Botanical Garden 63:277289.

- 1977. Pollen-ovule ratios: a conservative indicator of breeding systems in flowering plants. Evolution 31:3246.

Feinsinger, P. 1978. Interactions between plants and hummingbirds in a successional tropical community. Ecological Monographs 48:269-287.

- 1983. Coevolution and pollination. Pages 282-310 in D. J. Futuyma and M. Slatkin, editors. Coevolution. Sinauer Associates, Sunderland, Massachusetts, USA.

Feinsinger, P., W. H. Busby, K. G. Murray, W. Z. Pounds, and Y. B. Linhart. In press. Mixed support for spatial heterogeneity in species interactions: hummingbirds in a tropical disturbance mosaic. American Naturalist.

Feinsinger, P., and R. K. Colwell. 1978. Community organization among neotropical nectar-feeding birds. American Zoologist 18:779-795.

Feinsinger, P., Y. B. Linhart, L. A. Swarm, and J. A. Wolfe. 1979. Aspects of the pollination biology of three Erythrina species on Trinidad and Tobago. Annals of the Missouri Botanical Garden 66:451-471.

Feinsinger, P., K. G. Murray, S. Kinsman, and W. H. Busby. 1986. Floral neighborhood and pollination success in four hummingbird-pollinated cloud forest plant species. Ecology 67:449-464.

Feinsinger, P., J. A. Wolfe, and L. A. Swarm. 1982. Island ecology: reduced hummingbird diversity and the pollination biology of plants, Trinidad and Tobago, West Indies. Ecology 63:494-506.

Gadgil, M., and O. T. Solbrig. 1972. The concept of $r$ and $K$ selection: evidence from wild flowers and some theoretical considerations. American Naturalist 108:889-894.

Garwood, N. C., D. P. Janos, and N. Brokaw. 1979. Earthquake-caused landslides: a major disturbance to tropical forests. Science 205:997-999.

Grant, V. 1975. Genetics of flowering plants. Columbia University Press, New York, New York, USA.

Holdridge, L. R. 1967. Life zone ecology. Tropical Science Center, San Jose, Costa Rica.

Hollander, M., and D. A. Wolfe. 1973. Nonparametric statistical methods. J. Wiley and Sons, New York, New York, USA.

Jain, S. K. 1976. The evolution of inbreeding in plants. Annual Review of Ecology and Systematics 7:469-495.

Kellman, M. 1980. Geographic patterning in tropical weed communities and early secondary succession. Biotropica 12 (Supplement):34-39.

Lawton, R., and V. Dryer. 1980. The vegetation of the Monteverde Cloud Forest Reserve. Brenesia 18:101-116.

Levin, D. A., and H. W. Kerster. 1974. Gene flow in seed plants. Evolutionary Biology 7:139-220.

Levin, S. A. 1976. Population dynamics models in heterogeneous environments. Annual Review of Ecology and Systematics 7:287-310. 
Linhart, Y. B. 1973. Ecological and behavioral determinants of pollen dispersal in hummingbird-pollinated Heliconia. American Naturalist 107:511-523.

Linhart, Y. B., and P. Feinsinger. 1980. Plant-hummingbird interactions: effects of island size and degree of specialization on pollination. Journal of Ecology 68:745-760.

Linhart, Y. B., P. Feinsinger, J. H. Beach, W. H. Busby, K. G. Murray, W. Z. Pounds, S. Kinsman, C. A. Guindon, and M. Kooiman. 1987. Disturbance and predictability of flowering patterns in bird-pollinated cloud forest plants. Ecology, in press.

Marks, P. L. 1983. On the origin of the field plants of the northeastern United States. American Naturalist 122:210228.

McDade, L. A., and S. Kinsman. 1980. The impact of floral parasitism in two neotropical hummingbird-pollinated plant species. Evolution 34:944-958.

Murray, K. G. 1986. Consequences of seed dispersal for gap-dependent plants: relationships between seed shadows, germinution requirements, and forest dynamic processes. Pages 187-198 in A. Estrada and T. H. Fleming, editors. Frugivores and seed dispersal. Dr. W. Junk, Dordrecht, The Netheriands.

Newell, S. J., and E. J. Tramer. 1978. Reproductive strategies in herbaceous plant communities during succession. Ecology 59:228-234.

Oka, H-I. 1983. Life-history characteristics and colonizing success in plants. American Zoologist 23:99-109.

Opler, P. A., H. G. Baker, and G. W. Frankie. 1980. Plant reproductive characteristics during secondary succession in neotropical lowland forest ecosystems. Biotropica 12 (Supplement):40-46.

Parrish, J. A. D., and F. A. Bazzaz. 1979. Differences in pollination niche relationships in early and late successional plant communities. Ecology 60:597-610.

Pickett, \$. T. A. 1976. Succession: an evolutionary interpretation. American Naturalist 110:107-119.

Pickett, S. T. A., and P. S. White, editors. 1985. The ecology of natural disturbance and patch dynamics. Academic Press, New York, New York, USA.

Root, R. G. 1967. The niche exploitation pattern of the blue-gray gnatcatcher. Ecological Monographs 37:317-350.

Runkle, J. R. 1985. Disturbance regimes in temperate forests. Pages 17-34 in S. T. A. Pickett and P. S. White, editors. The ecology of natural disturbance and patch dynamics. Academic Press, New York, New York, USA.

Schmitt, J. 1980. Pollinator foraging behavior and gene dispersal in Senecio (Compositae). Evolution 34:934-943.

Schowalter, T. D. 1985. Adaptations of insects to disturbance. Pages 235-252 in S. T. A. Pickett and P. S. White, editors. The ecology of natural disturbance and patch dynamics. Academic Press, New York, New York, USA.

Siegel, S. 1956. Nonparametric statistics for the behavioral sciences. McGraw-Hill, New York, New York, USA.

Snow, D. W., and B. K. Snow. 1980. Relationships between hummingbirds and flowers in the Andes of Colombia. Bulletin of the British Museum (Natural History), Zoology 38: 105-139.
Sousa, W. P. 1984. The role of disturbance in natural communities. Annual Review of Ecology and Systematics 15: 353-391.

- 1985. Disturbance and patch dynamics on rocky intertidal shores. Pages 101-124 in S. T. A. Pickett and P. S. White, editors. The ecology of natural disturbance and patch dynamics. Academic Press, New York, New York, USA.

Stebbins, G. L. 1957. Self fertilization and population variability in the higher plants. American Naturalist 91:337354.

1958. Longevity, habitat, and release of variability in the higher plants. Cold Spring Harbor Symposium on Quantitative Biology 23:365-378.

Stiles, F. G. 1975. Ecology, flowering phenology, and hummingbird pollination of some Costa Rican Heliconia species. Ecology 56:285-301.

- 1978. Ecological and evolutionary implications of bird pollination. American Zoologist 18:715-727.

-1981. Geographical aspects of bird-flower coevolution, with particular reference to Central America. Annals of the Missouri Botanical Garden 68:323-351.

- 1985. Seasonal patterns and coevolution in the hummingbird-flower community of a Costa Rican subtropical forest. Pages 757-787 in P. A. Buckley, M. S. Foster, E. S. Morton, R. S. Ridgely, and F. G. Buckley, editors. Neotropical ornithology. Ornithological Monographs Number 36, American Ornithologists' Union, Lawrence, Kansas, USA.

Thompson, J. N. 1982. Interaction and coevolution. Wiley, New York, New York, USA.

Waser, N. M. 1982. A comparison of distances flown by different visitors to flowers of the same species. Oecologia (Berlin) 55:251-257.

Webb, C.J. 1984. Hummingbird pollination of Malvaviscus arboreus in Costa Rica. New Zealand Journal of Botany 22: 575-581.

Webb, C. J., and K. S. Bawa. 1983. Pollen dispersal by hummingbirds and butterflies: a comparative study of two lowland tropical plants. Evolution 37:1258-1270.

Werner, P. A., and W. J. Platt. 1976. Ecological relationships of co-occurring goldenrods (Solidago: Compositae). American Naturalist 110:959-971.

White, P. S. 1979. Pattern, process and natural disturbance in vegetation. Botanical Review 45:229-299.

Whitmore, T. C. 1978. Gaps in the forest canopy. Pages 639-655 in P. B. Tomlinson and M. H. Zimmermann, editors. Tropical trees as living systems. Cambridge University Press, New York, New York, USA.

Whittaker, R. H., and S. A. Levin. 1977. The role of mosaic phenomena in natural communities. Theoretical Population Biology 12:117-139.

Williams, G. C. 1975. Sex and evolution. Princeton University Press, Princeton, New Jersey, USA.

Willmer, P. G., and S. A. Corbet. 1981. Temporal and microclimatic partitioning of the floral resources of Justicia aurea amongst a concourse of pollen vectors and nectar robbers. Oecologia (Berlin) 51:67-78. 